\title{
PROLIFERATION RESISTANCE ASSESSMENT OF INDONESIAN 10-MWT RDE EXPERIMENTAL POWER REACTOR USING INPRO METHODOLOGY
}

\author{
Bening Farawan, Muhammad Sukron Fajrin Husein, Agus Sunarto, Arief Sasongko Adhi \\ Pusat Teknologi Bahan Bakar Nuklir - BATAN \\ Kawasan PUSPIPTEK Serpong Gd.20 Tangerang Selatan, Banten 15314 \\ e-mail: m.sukron@batan.go.id
}

(Naskah diterima: 04-10-2019, Naskah direvisi: 16-12-2019, Naskah disetujui: 07-01-2020)

\begin{abstract}
PROLIFERATION RESISTANCE ASSESSMENT OF INDONESIAN 10-MWT RDE EXPERIMENTAL POWER REACTOR USING INPRO METHODOLOGY. Assessment of proliferation resistance (PR) for 10-MWt RDE has been conducted to verify the RDE safeguards desain. Proliferation resistance (PR) is a parameter that can be used to measure the ability of a facility to implement safeguards (safeguardability). Safeguards is every technical measure used to ensure that every nuclear material in a facility is used as declared and only for welfare. Proliferation resistance of 10-MWt RDE has been assessed with INPRO methodology. The areas assessed were specific to intrinsic features of RDE, which consist of the attractiveness of nuclear material and technology and also detectability and chances of diversion of the nuclear material. This assessment concludes that the 10-MWt RDE has strong proliferation resistance, which indicates that the facility has small ability to diverse nuclear material and will less likely be used to proliferate nuclear weapon.
\end{abstract}

Keywords: Proliferation Resistance, Safeguards, INPRO Methodology. 


\section{ABSTRAK}

PENILAIAN KETAHANAN PROLIFERASI REAKTOR DAYA EKSPERIMENTAL (RDE) 10-MWT MENGGUNAKAN METODE INPRO. Penilaian ketahanan proliferasi (PR) untuk reaktor RDE $10 \mathrm{MWt}$ telah dilakukan untuk meverifikasi desain sistem seifgard pada RDE. Ketahanan proliferasi merupakan sebuah parameter yang dapat digunakan untuk mengukur kemampuan penerapan sistem seifgard (safeguardability) pada suatu fasilitas. Seifgard adalah segala upaya teknis yang dilakukan untuk memastikan bahwa bahan nuklir digunakan untuk tujuan damai. Penilaian ketahanan proliferasi dilakukan menggunakan metode INPRO. Penilaian ketahanan proliferasi dilakukan untuk fitur instrinsik RDe yang meliputi daya tarik bahan nuklir dan teknologi untuk proliferasi, kemampuan deteksi kegiatan proliferasi dan kemudahan diversi bahan nuklir. Penilaian ketahanan proliferasi menunjukkan bahwa Fasilitas RDE 10-MWt memiliki ketahanan proliferasi yang kuat. Hasil tersebut menandakan bahwa fasilitas ini memiliki memiliki kemampuan yang kecil untuk digunakan dalam kegeiatan proliferasi bahan nuklir.

Kata Kunci: Ketahanan Proliferasi, Seifgard, INPRO 


\section{INTRODUCTION}

\section{Treaty on the Non-Proliferation of Nuclear Weapons (NPT)}

According to Treaty on the NonProliferation of Nuclear Weapons (NPT), there are two kinds of states as parties to the treaty: Nuclear Weapon States (NWS) and Non-Nuclear Weapon States (NNWS)[1]. International Atomic Energy Agency (IAEA) along with state level authority must supervise the use of nuclear material in a NNWS[1]. NPT serve as prove of understanding and commitment of both parties to only use nuclear technology for peaceful purposes. NPT aims to eliminate the threat of nuclear war and the halm of nuclear weapon. NPT directs NWS to keep their nuclear weapon and nuclear weapon technology for themself and NNWS not to accept any nuclear weapon or nuclear weapon technology. Nuclear facilities have to fulfill the NPT requirements before being established. The requirement is to prove that the state will not use nuclear facility to proliferate nuclear material or to use nuclear material for harmful purposes.

\section{RDE Experimental Power Reactor}

Indonesia as a NNWS have been developing nuclear technology since 1958 with the establishment of Lembaga Tenaga Atom (Atomic Energy Institue) that changed into BATAN (National Nuclear Energy Agency). RDE Experimental Power Reactor is BATAN's most recent project to demonstrate the feasibility of nuclear power in Indonesia. The 10-MWt High Temperature Gas Cooled Reactor (HTGR) as an experimental power reactor is currently in a detailed engineering design phase. The safeguards design of the $10-\mathrm{MWt} R D E$ is needed for the project to achieve its construction permit from the regulatory body (BAPETEN). Figure 1 shows the details of a pebble fuel used in HTGR[2]. The fuel handling system of the RDE separates fresh, spent, and damaged fuels. The semi- automatic system in the RDE decreases human contact in refuelling the reactor core. The un-abliity to gve unique identification for each pebble due to small pebble size $(6 \mathrm{~cm}$ each) make RDE a bulk facility[3].

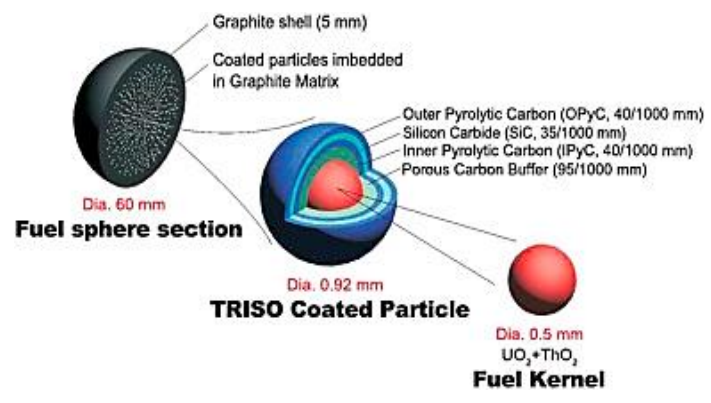

Figure 1. Pebble and TRISO fuel details[2].

\section{Safeguards and Proliferation Resistance}

Safeguards is every technical measure used to ensure the use of nuclear material is only for peaceful purposes. Key measurement point (KMP) is a place or area inside Material Balance Area (MBA) or facility such as reactor where nuclear material can be precisely accounted[4]. The formation of each key measurement point in the 10-MWt RDE is showed in Figure 2[3].

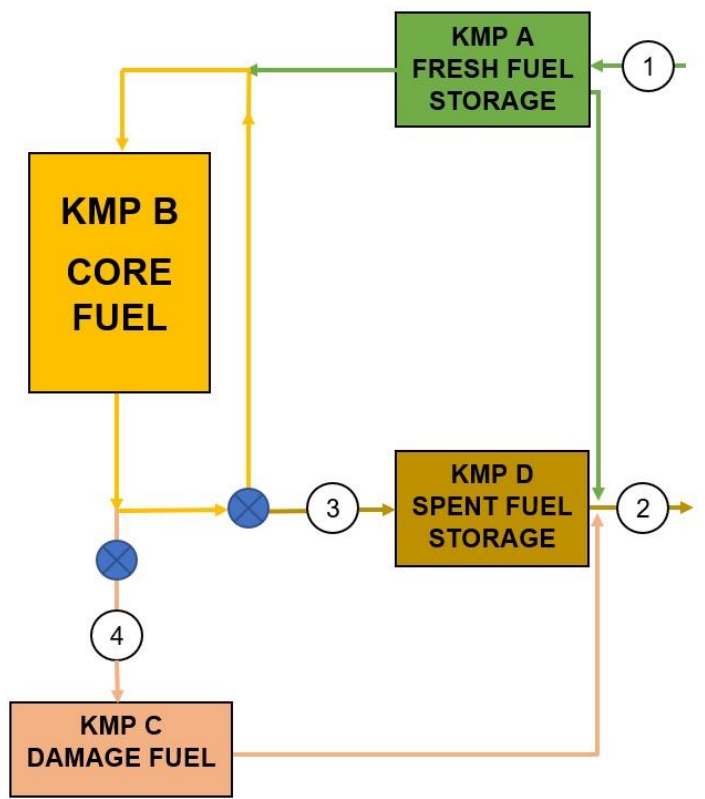

Figure 2. Key Measurement Points (KMP) of 10-MWt RDE; the inventory KMPs are noted in letters $(A, B, C, D)$ and flow KMPs are noted in numbers $(1$, 2, 3, 4)[2]. 
Proliferation Resistance (PR) is a parameter that can be used to measure how strong a facility is to prevent proliferation to happen. A facility or innovative nuclear system (INS) with high PR is less likely to or have lower ability to proliferate the nuclear material[5]. Both intrinsic features and extrinsic measures simultaneously affect the strength of proliferation resistance[6]. Intrinsic features of a nuclear reactor in example are design of the reactor, also shape and type of nuclear material used. Extrinsic measures that affected the PR are state's commitment to the NPT, safeguards system established in the state or facility, also export control policy of nuclear material and technology. PR and Safeguards.

Assessing the proliferation resistance of an INS can help in establishing an ideal safeguards system within a facility. Assessment result of PR can give reference and suggestion about which part of the INS that needs improvement in order to establish the safeguards system. There are various method in assessing proliferation resistance, one of them is proliferation resistance and physical protection assessment by Generation IV International Forum, and the other method is INPRO from International Atomic Energy Agency (IAEA) . International Project on Innovative Nuclear Reactors and Fuel Cycles (INPRO) is an initiative launched by IAEA in the year 2000. INPRO goal is to help and ensure the sustainability of nuclear energy available in $21^{\text {st }}$ century[7]. INPRO gains its goal using sets of basic principles to evaluate an INS before being established with a purpose to ensure that the INS is sustainable in every important area. The innovative nuclear system (INS) has to achieve basic principles in economic, infrastructure, waste management, proliferation resistance, physical protection, environment, and safety. INPRO methodology uses the value of each basic principle to evaluate sustainability of the INS. INPRO methodology is choosen because it have more comprehensive assessment parameter compared to other methods.

INPRO methodology for evaluating proliferation resistance has one basic principle. The basic principle for proliferation resistance is "PR intrinsic features and extrinsic measures shall be implemented throughout the full life cycle for INS to help ensure that INS will continue to be an unattractive means to acquire fissile material for a nuclear weapon programme. Both intrinsic features and extrinsic measures are essential, and neither shall be considered sufficient by itself'[8].

INPRO methodology has five user requirements (UR) to fulfil the $P R$ basic principle. The user requirements for evaluating PR are (1) state's commitments, obligations and policies regarding nonproliferation and its implementation should be adequate to fulfill international standards in the non-proliferation regime; (2) the attractiveness of nuclear material and technology in an INS for a nuclear weapons programme should be low; (3) the diversion of nuclear material should be reasonably difficult and detectable; (4) INS should incorporate multiple PR and measures; (5) INS should optimize the combination of intrinsic features and extrinsic measures in the design/engineering phase to provide cost-efficient PR[8].

Assessment of PR in 10-MWt RDE in Indonesia gives broader knowledge on how to implement safeguards, by design or not, in early stage. The knowledge of safeguards implementation can be used in the future if Indonesia wants to establish a nuclear power plant. Understanding of proliferation resistance can deepen safeguards implementation and help operator to study weaknesses of facility to nuclear material proliferation. The weaknesses of facility can be an important data for operator and state to use safeguards by design before the facility is established. 


\section{METHODS}

The evaluation that has been conducted in this paper was focused on the intrinsic features of the 10-MWt RDE. Intrinsic features cover UR 2 and UR 3 in the INPRO methodology. Evaluation was carrued out by comparing points of indicator in each user requirement with the data from basic engineering design of the 10-MWt RDE written in the safeguards system of RDE. Table 1 shows the example of UR 2 evaluation details. Table 1 only serve as an example of data that will be discussed.

Table 1. Example from some indicator taken from UR 2 and UR 3 combined [8]

\begin{tabular}{|c|c|c|c|c|c|c|c|}
\hline \multirow{2}{*}{ Indicators } & \multirow{2}{*}{ No } & \multirow{2}{*}{$\begin{array}{l}\text { Evaluation } \\
\text { Parameter }\end{array}$} & \multicolumn{5}{|c|}{ Evaluation Scale } \\
\hline & & & vW & W & $M$ & S & VS \\
\hline \multirow{4}{*}{$\begin{array}{l}\text { Material } \\
\text { Quality } \\
\text { (UR2) }\end{array}$} & 1 & Material Type & UDU & IDU & LEU & $\mathrm{NU}$ & DU \\
\hline & 2 & ${ }^{239} \mathrm{Pu} / \mathrm{Pu}(\% \mathrm{wt})$ & & $>50$ & & $<50$ & \\
\hline & 3 & Dose (mGy/hr) at $1 \mathrm{~m}$ & $<150$ & $150-350$ & $350-1000$ & $1000-10000$ & $>10000$ \\
\hline & 4 & ${ }^{238} \mathrm{Pu} / \mathrm{Pu}$ (\%wt) & & $<20$ & & $>20$ & \\
\hline \multirow{3}{*}{$\begin{array}{l}\text { Material } \\
\text { Quantity } \\
\text { (UR2) }\end{array}$} & 5 & Mass of an item $(\mathrm{kg})$ & 10 & $10-100$ & $100-500$ & $500-1000$ & $>1000$ \\
\hline & 6 & $\begin{array}{l}\text { Mass of bulk } \\
\text { material for } \mathrm{SQ}\end{array}$ & 10 & $10-100$ & $100-500$ & $500-1000$ & $>1000$ \\
\hline & 7 & $\begin{array}{l}\text { No. of SQs (material } \\
\text { stock or flow) }\end{array}$ & $>100$ & $50-100$ & $10-50$ & $1-10$ & $<1$ \\
\hline $\begin{array}{l}\text { Accountability } \\
\text { (UR3) }\end{array}$ & 8 & $\sigma_{M U F} / S Q$ & $>2$ & $2 \sim 1$ & $1 \sim 0.5$ & $0.5 \sim 0.1$ & $<0.1$ \\
\hline
\end{tabular}

User requirement as shown in the table above can be evaluated by choosing one of the data in evaluation scale according to information from the safeguards system. The scale is ranged from Very Weak (VW), Weak (W), Medium (M), Strong (S), and Very Strong (VS). The final score of proliferation resistance can then be calculated by the mean of every scale evaluated. Evaluation parameter that only has weak or strong scale such as ${ }^{239} \mathrm{Pu} / \mathrm{Pu}$ (\%wt) in example above is also present in UR 2 and UR 3 . The total score will be counted with the scale of 1 to 5 .
Very weak resistance will give 1 score while very strong resistance will give 5 score. The score then will be divided by numbers of parameter evaluated. The average score will be rounded to the nearest round number to indicate the result of each UR from very weak to very strong. Evaluation parameter number 6 and 7 needs to be counted from the data of RDE detailed design information [9]. Evaluation parameter number 6 will be counted using Equation 1 and evaluation parameter number 7 will be counted using Equation 2.

$$
\begin{aligned}
& \text { Mass for } S Q=\frac{S Q \text { for Uranium }}{\text { Mass of } U \text { in Pebble }} \times \text { Mass of Each Pebble } \\
& \text { Number of Item for } S Q=\frac{\text { Mass for } S Q}{\text { Mass of a pebble }}
\end{aligned}
$$




\section{RESULTS AND DISCUSSION}

\section{Evaluation of User Requirement 2 Attractiveness of Nuclear Material and Technology}

Evaluation of User Requirement (UR) 2 was done using a total of 14 evaluation parameters. Table 2 shows the evaluation result of UR 2. The first indicator is material quality with evaluation parameter number one is material type. The material type is divided based on uranium enrichment and use. The Directly Used High Enriched Uranium (UDU) have very weak proliferation resistance, followed by Indirectly Used High Enriched Uranium (IDU) as eak, Low enriched Uranium (LEU) as Medium, Natural Uranium (NU) in strong, and Depleted Uranium (DU) in Very Strong proliferation resistance. The 10-MWt RDE uses uranium with an initial enrichment of $17 \%[9]$ which is classified as low enriched uranium (LEU). LEU as the material type gave this facility a medium score of proliferation resistance. Evaluation parameters 2 to 6 could not be determined. Parameters 2, 5 and 6 about certain plutonium isotopes to mean of all the plutonium presents could not be determined due to lack of neutronic information of the pebble spent fuel. Currently there are no data of post irradiation examination in pebble fuel or any HTGR fuel. Dose rate of the fuel and spent fuel could not be evaluated because lack of information in dose calculation of the TRISO fuel. Another parameter which could not be evaluated is the ratio of ${ }^{232} \mathrm{U}$ contamination to ${ }^{23} \mathrm{U}$ present. It could not be determined because the pebble fuels do not use ${ }^{233} \mathrm{U}$ as fissile material.

The second indicator is material quantity that indicate number (in quantity or element mass) needed to reach one significant quantity (SQ). A significant quantity is the amount of nuclear material that can fulfil the needs of manufacturing a nuclear explosive device[10]. The 10-MWt RDE has 27,000 fuel pebbles in one reactor. Each pebble weighs 200 grams with 5 grams of uranium[10]. One $S Q$ for indirect use low enriched uranium $(235 \mathrm{U}<20 \%)$ is $75 \mathrm{~kg}[10]$.

Mass of an item indicates the difficulties in diversion of material. The lighter the mass of an item the easier to diverse the item. The mass of each fuel pebble is 200 grams that gave the score of weakest proliferation resistance. Although the proliferation resistance in nuclear fuel weight is weak, the proliferation resistance from number to reach $1 \mathrm{SQ}$ is strong. The more mass or number of items needed for $1 \mathrm{SQ}$, the harder it is to proliferate that nuclear material. Equation 1 shows the calculation for mass of bulk material needed for $1 \mathrm{SQ}$, while Equation 2 shows the calculation for number of items needed to reach $1 \mathrm{SQ}$. According to the calculation from equation 1 , total pebble mass for $1 \mathrm{SQ}$ is $3000 \mathrm{~kg}$ indicating very strong proliferation resistance. Number of items also shows 15,000 pebbles are needed to reach 1 $S Q$ that indicates very strong proliferation resistance.

The last evaluation parameter in this indicator is the number of $S Q$ in one process or stage. As we know from the result before, the number of fuel pebbles to reach $1 S Q$ is 15,000 while the number of fuel pebbles in the reactor is 27,000 . By dividing the total number of pebbles in one reactor by number of pebbles needed for $S Q$, we get the result that the 10-MWt RDE core has a total of 1.8 $S Q$ of uranium. This number indicates a strong proliferation resistance because the reactor has only slightly less than $2 \mathrm{SQ}$ if it were to be used for harmful purposes.

The third indicator is material classification. Physical and chemical properties of a material affect the difficulty to extract the nuclear material for harmful purposes. The TRISO fuel pebble is categorized as compound because uranium inside the fuel is mixed with graphite and other support material making it difficult to extract [11]. The result of evaluation indicates that the pebble fuel has medium proliferation resistance due to the difficultness in extracting the nuclear material. 
Table 2. General Evaluation Results of UR 2: Attractiveness of Nuclear Material and Technology

\begin{tabular}{|c|c|c|c|c|c|c|c|}
\hline \multirow{2}{*}{ Indicators } & \multirow{2}{*}{ No } & \multirow{2}{*}{$\begin{array}{l}\text { Evaluation } \\
\text { Parameter }\end{array}$} & \multicolumn{5}{|c|}{ Evaluation Scale } \\
\hline & & & VW & $W$ & $\mathrm{M}$ & $S$ & VS \\
\hline \multirow{6}{*}{$\begin{array}{l}\text { Material } \\
\text { Quality }\end{array}$} & 1 & Material Type & UDU & IDU & LEU $\sqrt{ }$ & $\mathrm{NU}$ & DU \\
\hline & 2 & ${ }^{239} \mathrm{Pu} / \mathrm{Pu}(\% \mathrm{Wt})$ & & $>50$ & & $<50$ & \\
\hline & 3 & $\begin{array}{l}\text { 232Ucontam for } \\
{ }^{233} \mathrm{U}(\mathrm{ppm})\end{array}$ & $<400$ & $400-1000$ & $1000-2500$ & $2500-25000$ & $>25000$ \\
\hline & 4 & $\begin{array}{l}\text { Dose (mGy/hr) at } \\
1 \mathrm{~m}\end{array}$ & $<150$ & $150-350$ & $350-1000$ & $1000-10000$ & $>10000$ \\
\hline & 5 & ${ }^{238} \mathrm{Pu} / \mathrm{Pu}(\% \mathrm{wt})$ & & $<20$ & & $>20$ & \\
\hline & 6 & $\begin{array}{l}\left({ }^{240} \mathrm{Pu}+{ }^{242} \mathrm{Pu}\right) / \mathrm{Pu} \\
(\% \mathrm{wt})\end{array}$ & & & & & \\
\hline \multirow{4}{*}{$\begin{array}{l}\text { Material } \\
\text { Quantity }\end{array}$} & 7 & $\begin{array}{l}\text { Mass of an item } \\
(\mathrm{kg})\end{array}$ & $\begin{array}{l}>10 \\
(200 \mathrm{~g})\end{array}$ & $10-100$ & $100-500$ & $500-1000$ & $>1000$ \\
\hline & 8 & $\begin{array}{l}\text { Mass of bulk } \\
\text { material for SQ } \\
(\mathrm{kg})\end{array}$ & 10 & $10-100$ & $100-500$ & $500-1000$ & $\begin{array}{l}>1000 \\
(3000)\end{array}$ \\
\hline & 9 & $\begin{array}{l}\text { No. of items for } \\
\text { SQ }\end{array}$ & 1 & $1-10$ & $10-50$ & $50-100$ & $\begin{array}{c}>100 \\
(15000)\end{array}$ \\
\hline & 10 & $\begin{array}{l}\text { No. of SQs } \\
\text { (material stock or } \\
\text { flow) }\end{array}$ & $>100$ & $50-100$ & $10-50$ & $1-10(1,8)$ & $<1$ \\
\hline $\begin{array}{l}\text { Material } \\
\text { Classification }\end{array}$ & 11 & $\begin{array}{l}\text { Chemical/physical } \\
\text { form }\end{array}$ & Metal & Oxide & $\begin{array}{c}\text { Com- } \\
\text { pounds } \sqrt{ }\end{array}$ & Spent Fuel & Waste \\
\hline \multirow{3}{*}{$\begin{array}{l}\text { Nuclear } \\
\text { Technology }\end{array}$} & 12 & Enrichment & & Yes & & No $\sqrt{ }$ & \\
\hline & 13 & $\begin{array}{l}\text { Extraction of } \\
\text { fissile material }\end{array}$ & & Yes & & No $\sqrt{ }$ & \\
\hline & 14 & $\begin{array}{l}\text { Irradiation } \\
\text { capability of } \\
\text { undeclared fertile } \\
\text { material }\end{array}$ & & Yes & & No $\sqrt{ }$ & \\
\hline
\end{tabular}

*Unevaluated parameter is colored in red while selected scale in a parameter is colored in green

The final indicator of UR 2 is nuclear technology. According to engineering design, none of those features are available in the 10$\mathrm{MWt}$ RDE. The $10 \mathrm{MWt} R D E$ is only a reactor facility planned without any sample irradiation facility. RDE also have semi-automatic fuel handling system that makes the reactor can only accept pebble fuel with corresponding sphericity. The fuel for 10-MWt RDE will be imported, and the enrichment will be done by the manufacturer so there is no enrichment facility inside the reactor. RDE is also not designed with post irradiation examination lab or facility.

The evaluation of UR 2 gave results of one parameter with very weak resistance, two parameters with medium resistance, four parameters with strong resistance, and two parameters with very strong resistance. The total score of UR 2 is 33 with nine parameters evaluated and five parameters unevaluated. The average score of UR 2 is 3.6 or rounded to 4 that indicates that the proliferation resistance seen from the attractiveness of nuclear material and technology is strong. 


\section{Evaluation of UR 3 Diversion and Detectability of Nuclear Material.}

Evaluation of UR 3 was done using a total of 13 evaluation parameters. The parameters are divided in five indicators as can be seen in Table 3. Every evaluation parameter and indicator will be evaluated with the data of basic engineering design and data from reactor that already established in Indonesia. The established reactor data can also be used even if the reactor is not the same type as RDE. The established reactor data will be used as reference of reactor operation and amendability of safeguards system implemented in established reactors. Table 3 shows the evaluation of UR 3 .

The accountability indicator mean that every nuclear material present must be accounted. The total MUF to SQ ratio show how much nuclear material can be lost (unaccounted) compared to number of SQ. The 10-MWt RDE is analyzed to be bulk facility, but the characteristic of pebble that contain nuclear material can avoid MUF in process or handling system [12]. The unique characteristic of pebble fuel and RDE facility make the facility is declared as bulk facility with expected zero MUF from the process. The expected MUF can come from measurement uncertainty in each KMP. Approximately, number of MUF can be close to the amount of uncertainty of any measurement tool used in the facility [13]. Evaluation parameter of total MUF to SQ ratio is scored very high with the value of 0.1 meaning there are less than 0.1 SQ of total MUF that is expected to occur in the facility. The value of MUF is acquired from the refrence of similar reactor [13] and International Target Values (ITV) for measurement in safeguards application [14]

The inspector measurement capability parameter of this indicator evaluates the way inspector can measure the nuclear material inside the facility. Each Fresh pebble nuclear fuel has thousands of TRISO particle around the $6 \mathrm{~cm}$ pebble fuel [2]. The well distributed TRISO particle has uranium and its decay daughter inside which can expose gamma radiation that enables NonDestructive Analysis. Therefore, the NDA passive can be applied to analyze pebble fuel. This parameter is evaluated by knowledge the inspector can get from the inspection that affect chance of nuclear material diversion. The NDA passive ease of measurement are better than item counting and NDA active. These advantages of NDA passive analysis gave very strong proliferation resistance.

The second indicator is amenability of containment and surveillance (C/S) system and other monitoring system. This indicator means that the facility must have a proper system that can answer the need of nuclear material containment and surveillance. The need of $\mathrm{C} / \mathrm{S}$ system is the continuation of knowledge in the amount and place of nuclear material. The containment system serves as a way to keep nuclear material in a place where it should be ensuring there are no diversion happen. The surveillance system serves as a way for authority (state or international level) to have the knowledge of the activity that happen around or related to the nuclear material. The monitoring system serve as a support system of both the containment and surveillance. This indicator with three parameters is evaluated by comparing the history of three nuclear reactor that already established. All of Indonesia's research reactors have already established an amendable C/S system. One of the examples for the success in $\mathrm{C} / \mathrm{S}$ system implementation is in Indonesia Multipurpose Reactor G.A Siwabessy [15]. The amenability is proven by both state and international authorities to Indonesian National Nuclear Energy Agency (BATAN). The past experience got from other installations ensures that $\mathrm{C} / \mathrm{S}$ system also other monitoring system that will be equipped in RDE will be amendable. 
Table 3. General Evaluation Results of UR3: Diversion and Detectability of Nuclear Material

\begin{tabular}{|c|c|c|c|c|c|c|c|}
\hline \multirow{2}{*}{ Indicators } & \multirow{2}{*}{ No } & \multirow{2}{*}{$\begin{array}{l}\text { Evaluation } \\
\text { Parameter }\end{array}$} & \multicolumn{5}{|c|}{ Evaluation Scale } \\
\hline & & & VW & $W$ & $M$ & $S$ & VS \\
\hline \multirow[b]{2}{*}{ Accountability } & 1 & $\sigma_{M U F} / S Q$ & $>2$ & $2 \sim 1$ & $1 \sim 0.5$ & $0.5 \sim 0.1$ & $<0.1$ \\
\hline & 2 & $\begin{array}{l}\text { Inspectors' } \\
\text { measurement } \\
\text { capability }\end{array}$ & IC only & DA only & $\begin{array}{l}\text { DA } \\
\text { and } \\
\text { NDA }\end{array}$ & NDA Active & $\begin{array}{l}\text { NDA } \\
\text { Passive }\end{array}$ \\
\hline \multirow{3}{*}{$\begin{array}{l}\text { Amenability for } \\
\mathrm{C} / \mathrm{S} \text { and- } \\
\text {-monitoring } \\
\text { systems }\end{array}$} & 3 & $\begin{array}{l}\text { Amenability of } \\
\text { containment } \\
\text { measures }\end{array}$ & & No & & Yes & \\
\hline & 4 & $\begin{array}{l}\text { Amenability of } \\
\text { surveillance } \\
\text { measures }\end{array}$ & & No & & Yes & \\
\hline & 5 & $\begin{array}{l}\text { Amenability of } \\
\text { other monitoring } \\
\text { systems }\end{array}$ & & No & & Yes & \\
\hline \multirow{2}{*}{$\begin{array}{l}\text { Detectability of } \\
\text { nuclear } \\
\text { material }\end{array}$} & 6 & $\begin{array}{l}\text { Possibility to } \\
\text { identify nuclear } \\
\text { material by NDA }\end{array}$ & & No & & Yes & \\
\hline & 7 & $\begin{array}{l}\text { Detectability of } \\
\text { radiation signature }\end{array}$ & & No & & Yes & \\
\hline \multirow{4}{*}{$\begin{array}{l}\text { Difficulty to } \\
\text { modify the } \\
\text { process }\end{array}$} & 8 & $\begin{array}{l}\text { Extent of } \\
\text { automation }\end{array}$ & $\mathrm{N} / \mathrm{A}$ & $\begin{array}{c}\text { Manual } \\
\text { Automation }\end{array}$ & $\mathrm{N} / \mathrm{A}$ & $\begin{array}{c}\text { Partial } \\
\text { Automation }\end{array}$ & $\begin{array}{c}\text { Full } \\
\text { Automation }\end{array}$ \\
\hline & 9 & $\begin{array}{l}\text { Availability of data } \\
\text { for inspectors }\end{array}$ & $\begin{array}{c}\text { Operator } \\
\text { Data }\end{array}$ & & & & NRTA \\
\hline & 10 & $\begin{array}{l}\text { Transparency of } \\
\text { process }\end{array}$ & & No & & Yes & \\
\hline & 11 & $\begin{array}{l}\text { Accessibility of } \\
\text { material to } \\
\text { inspectors }\end{array}$ & & No & & Yes & \\
\hline $\begin{array}{l}\text { Difficulty to } \\
\text { modify facility } \\
\text { design }\end{array}$ & 12 & $\begin{array}{l}\text { Verifiability of } \\
\text { facility design by } \\
\text { inspectors }\end{array}$ & & No & & Yes & \\
\hline $\begin{array}{l}\text { Detectability of } \\
\text { misuse of } \\
\text { technology or } \\
\text { facilities. }\end{array}$ & 13 & $\begin{array}{l}\text { Possibility to detect } \\
\text { misuse of the } \\
\text { technologies and } \\
\text { the INS facilities for } \\
\text { processing of } \\
\text { undeclared nuclear } \\
\text { material. }\end{array}$ & & No & & Yes & \\
\hline
\end{tabular}

*Unevaluated parameter is colored in red while selected scale in a parameter is colored in green

The third indicator is detectability of nuclear material. This indicator has two parameters: the possibility of detection by NDA and detection of radiation signature.. According to the safeguards system of 10 -
MWt RDE, the fuel used in the RDE have an initial enrichment of $17 \%$. The $17 \%$ enrichment of $235 \mathrm{U}$ emits gamma radiation of specific energy which can be both detected by NDA and give specific radiation signature. This 
detectability by NDA and specific radiation signature gave high proliferation resistance to the facility, specifically seen in detectability point of view.

The fourth indicator is difficulty to modify the process. There are two kinds of HTGR currently being developed: the first one is HTGR with fuel recycle system and the second one is HTGR with Once Trough Then Out (OTTO) system[16]. Both HTGR use automatic loading-unloading features where pebbles will be automatically fed to the reactor core and automatically unloaded after a specific period of time [16]. Once the pebble fuel was fed into the fuel recycle line, it will automatically be recycled. The circuit of the fuel ends after the fuel goes around the reactor for about 10 times. The spent fuel will also be automatically sent to the spent fuel storage. The spent fuel will be placed inside a storage canister and the canister will be placed in dry storage. This fuel cycle system is categorized as partial automation because the human or worker still interact with the fuel when feeding the fuel to the fuel line and in locking the spent fuel storage canister. The partial automation gave high proliferation resistance because it makes human difficult to modify the process or to diverse the nuclear material mid-process.

The second parameter in the fourth indicator is data availability for inspector. There are only two scales of this parameter: one is operator data that scaled very weak and the other is NRTA that scored very strong. NRTA stands for Near Real Time Accountancy where the inspector equips set of instruments in each KMP. This instrument will give the nuclear material accountancy data such as weight, and place in real time to the inspector in IAEA or state level. The NRTA system is not yet established in Indonesia. Therefore, making the RDE will only have operator data available for the inspector. The operator data make the 10-MWt RDE have very weak proliferation resistance because the data can be inaccurate or changed before the inspector see the data.
The third and fourth parameters of this indicator are transparency of the process and accessibility of material to inspector. This indicator evaluation depends on the willingness of the operator/state to demonstrate its level of transparency[17]. According to Indonesia's experience in doing the safeguards system, operator and state have a high level of transparency. Operator is willing to give all the information that inspector needs and state obliges the facility to follow every instruction to fulfil the safeguards agreement. This parameter gave high proliferation resistance due to Indonesia's experience in implementing the integrated safeguards agreement.

The fifth parameter is verifiability of design to inspector. The design verifiability parameter is evaluated in the same manner as the accessibility of material before. The willingness of operator/state to give information about the facility is an important factor in design verifiability. Design verifiability also affected by state commitment in implementing integrated safeguard agreement. According to Information Circular Number 288 Add 1 [18], Indonesia as a state has committed to accept any kind of inspection related to implementing integrated safeguards. One of the inspections is Complementary Access (CA) done by IAEA. One of the goals of the CA inspection is to verify correctness of information in the Additional Protocol declaration done by each facility. The state commitment and facility willingness make this parameter scored high proliferation resistance.

The last parameter of UR 3 is possibility to detect misuse of the technologies and the INS facilities for processing of undeclared nuclear material. The IAEA will likely use numbers of instrument such as fuel flow monitor to verify fuel transfer [19]. The flow monitor will help both operator and inspector to count, verify, and distinguish different types of pebbles such as fresh fuel and spent fuel pebble. The measurement done by flow monitor can be one of many 
methods to detect misuse of technology. Passive NDA such as multi-channel analyser spectrometer coupled in the flow monitor can also help differentiate pebble's content. The ability to acquire such information give this parameter a high proliferation resistance.

The evaluation of UR 3 gave one parameter with very weak proliferation resistance, ten parameters with strong proliferation resistance, and two parameter with very high proliferation resistance. Total score of UR 3 is 51 with 13 parameters all evaluated. The average score of UR 3 is 3.9 or rounded to 4 indicates that the 10-MWt RDE has a strong proliferation resistance seen from Diversion and Detectability of Nuclear Material requirement.

\section{CONCLUSION}

The 10-MWt RDE has strong proliferation resistance evaluated in terms of attractiveness of nuclear material and technology. The weakest parameter in this UR is the mass of each item. The pebble for RDE's fuel has a mass of $\mathbf{2 0 0}$ grams. This lightweight item can be easily taken under weak supervision. While the weakest parameter is the mass of item, the strongest parameter in this UR is mass of bulk material and number of items needed for SQ. The mass of bulk material needed for the uranium inside the fuel to reach $\mathrm{SQ}$ is $3000 \mathrm{~kg}$. This number indicates that an enormous mass is needed which makes the diversion harder and take longer time to fulfil the enormous mass of uranium needed. The number of pebbles needed to reach $S Q$ is 15,000 . This high amount of pebbles needed makes diversion easier to detect, therefore it strengthens the resistance of proliferation inside the facility. The 10-MWt RDE has strong proliferation resistance evaluated in terms of diversion and detectability of nuclear material. The weakest parameter in this UR is the available data for inspector. The strongest parameter in UR 3 is the ratio between MUF to SQ. MUF in RDE will only present as uncertainty of data due to the characteristic of process and nuclear material.
Further assessment in proliferation resistance and calculation of MUF are needed for RDE safeguards system to be comprehensively amendable. Wholesome knowledge about the sustainability of RDE and design improvement can be acquired by doing full INPRO assessment in proliferation resistance and other important areas such as economics and waste treatment.

\section{REFERENCES}

[1] Treaty on the Non-Proliferation of Nuclear Weapons (INFCIRC 140), International Atomic Energy Agency, Vienna, 1970.

[2] High Temperature Gas-cooled Reactor, Fuels and Material (TECDOC-1645), International Atomic Energy Agency, Vienna, 2010.

[3] Sistem Seifgard Reaktor Daya Eksperimental, Badan Tenaga Nuklir Nasional, 2016.

[4] International Safeguards in the Design of Facilities for Long Term Spent Fuel Management (NF-T-3.1), International Atomic Energy Agency, Vienna, 2018.

[5] Option to Enhance Proliferation Resistance of Innovative Small and Medium Sized Reactors (NP-T-1.11). International Atomic Energy Agency, Vienna, 2014.

[6] INPRO Collaborative Project: Proliferation Resistance: Acquisition Diversion Pathway Analysis / PRADA (TECDOC-1684), International Atomic Energy Agency, Vienna, 2012.

[7] Guidance for the Application of an Assessment Methodology for Innovative Nuclear Energy System (TECDOC-1575 Rev.1), International Atomic Energy Agency, Vienna, 2008.

[8] Guidance for the Application of an Assessment Methodology for Innovative Nuclear Energy System Vol.5 Proliferation Resistance (IAEATECDOC-1575), International Atomic Energy Agency, Vienna, 2007. 
[9] Pengembangan Desain Seifgard Reaktor Daya Eksperimental, Badan Tenaga Nuklir Nasional, 2018.

[10] IAEA Safeguards Glossary (IAEA/NVS/3), International Atomic Energy Agency, Vienna, 2001.

[11] Powers $J$ and Wirth D, "A review of TRISO fuels performance model", Journal of Nuclear Material, vol. 405, pp. 74-82, 2010.

[12] P. D. Winastri, B. Farawan and $H$. Wahyono, "Tinjauan Umum Material Accounted For (MUF) pada Desain RDE," Proceeding of Seminar Nasional Infrastruktur Energi Nuklir, Indonesia, 2018, pp. 1-6.

[13] K. Disser, E. Arthur and J. Lambert, "Preliminary safeguards assessment for the pebble-bed flouride high temperature reactor (PB-FHR)", Presented in Advances in Nuclear Nonproliferation and Policy Conference Proceeding, September 2016, Idaho, INL/CON-16-38642 Preprint.

[14] International Target Values 2010 for Measurement Uncertainty in Safeguarding Nuclear Materials (STR368), International Atomic Energy Agency, Vienna, 2010.
[15] D. T. Jatmiko and Azzriani "Kegiatan Seifgard di Reaktor Riset RSG-GAS sebagai Komitmen BATAN dalam Menjamin Pemanfaatan Bahan Nuklir untuk Tujuan Damai", Proceeding of Seminar Nasional Teknologi dan Aplikasi Reaktor Nuklir, Indonesia, 2012, pp. $176-184$.

[16] P. H. Liem, T. M. Sembiring and H. Tran, "Evaluation on fuel cycle and loading scheme of the Indonesian experimental power reactor design" Journal of Nuclear Engineering and Design, vol. 340, pp. $245-259,2018$.

[17] INPRO Assessment of the Planned Nuclear Energy System of Belarus (TECDOC-1716), International Atomic Energy Agency, Vienna, 2013.

[18] Protocol Additional to the Agreement Between the Republic of Indonesia and the International Atomic Energy Agency for the Application of Safeguards in Connection with the Treaty on the NonProliferation of Nuclear Weapons (INFCIRC 283 Add.1), International Atomic Energy Agency, Vienna, 1999.

[19] International Safeguards in the Design of Nuclear Reactors (NP-T-2.9), International Atomic Energy Agency, Vienna, 2014. 